Ročník XVII (2015), Číslo 2, s. 237-241/ Volume XVII (2015), Issue 2, pp. 237-241

(c) Mezinárodní politologický ústav / International Institute of Political Science

DOI: $10.5817 / C E P S R .2015 .2 .237$

\title{
Vlastimil Havlík a kol.: Volby do Poslanecké sněmovny 2013
}

Brno: Mezinárodní politologický ústav, 2014. 347 stran, ISBN: 9788021071476

\section{MARCELA VOŽENÍLKOVÁ ${ }^{1}$}

Další ze série knižních publikací zachycujících dění na české politické scéně se věnuje předčasným volbám do Poslanecké sněmovny, které proběhly na podzim roku 2013. Tým z Fakulty sociálních studií Masarykovy univerzity ve třinácti kapitolách podrobně popisuje dění kolem voleb, př́ičemž připojuje celou řadu tabulek a grafů pro lepší orientaci čtenáře $\mathrm{v}$ textu.

Pokud nepočítám úvodní slovo, tak první kapitola, jejímž autorem je Otto Eibl, analyzuje volební programy nových i tradičních subjektů účastnících se voleb. Vzhledem k charakteru voleb měly přitom pevnější postavení při sestavování svých programů politické strany, které na politickém trhu nějaký čas působily a svůj program proto mohly odvíjet od svého minulého působení, resp. čerpat ze svých „identit“. Podobně jako v předchozích volebních kláních přitom lze pozorovat približování se jednotlivých programových bodů a jen velmi těžko bychom hledali stranu, která by ve svém programu měla teze, jež by šly proti ideálům efektivního, funkčního, bezpečného a prosperujícího státu, který nabízí kvalitní nezkorumpovanou správu věcí veřejných a dostatečnou paletu sociálních služeb. Kromě sedmi subjektı̊, které v roce 2013 získaly parlamentní zastoupení (tedy ANO, ČSSD, KDU-ČSL, KSČM, ODS, TOP 09 a Úsvitu), posuzuje autor také program Strany zelených, a to z hlediska zastoupení sedmi tematických oblastí: zahraniční politika, svoboda a demokracie, politický systém a efektivita státu, ekonomika, sociální systém, společenské uspořádání, profesní skupiny. Z těchto skupin se nejčastěji zastoupenými tématy - a to u všech analyzovaných programů - staly otázky spojené s ekonomikou, technologickým rozvojem a budováním infrastruktury na straně jedné, a otázky týkající se nastavení sociálního systému, péče o kulturní dědictví a kulturu obecně, podoby školského systému a či péče o životní prostředí na straně druhé. Dle autora obsahovaly více pozičních výroků programy stran, které působily mimo půdu Poslanecké

${ }^{1}$ Katedra politologie, Fakulta sociálních studií, Masarykova univerzita, Brno, Česká republika / Department of Political Science, Faculty of Social Studies, Masaryk University, Brno, Czech Republic. E-mail: marcelavozenilkova@mail.muni.cz 
sněmovny, popř. těch, které byly $\mathrm{v}$ předchozím volebním období $\mathrm{v}$ opozici (s výjimkou KSČM a ANO). Právě hnutí ANO společně s TOP 09 prosazovaly nejvíce valenční programy. Autor kapitolu doplňuje o analýzu četnosti výskytu jazykových jednotek na úrovni slov (tzv. wordcloudy) a deskriptivní popis konkrétní nabídky politických stran před volbami 2013, a přináší tak ucelený pohled na programatiku stran ve volební kampani.

Právě volebním kampaním se věnuje další kapitola Miloše Gregora a Aleny Mackové. Jako následek pádu Nečasovy vlády a narychlo vypsaných voleb byly kampaně, na které si politické strany dříve vyhrazovaly stále více času, tentokrát rekordně krátké. S tím souvisle i fakt, že místo dosavadního fenoménu stále nákladnějších kampaní vynaložily politické strany v roce 2013 v porovnání $\mathrm{s}$ předchozími lety podstatně méně finančních prostředků. Na tomto místě je nutné upozornit, že vzhledem $\mathrm{k}$ rozsahu textu, který měl být $\mathrm{v}$ rámci publikace volebním kampaním věnován, nebylo možné detailně popsat všechny aspekty volebních kampaní (i vzhledem $\mathrm{k}$ počtu subjektů, kterým výzkumy veřejného mínění přiznávaly možné šance na zvolenî). Takový detailní popis však lze nalézt v publikaci Pavla Šímy, Marcely Králikové a kolektivu Volební kampané 2013 (Barrister \& Principal, 2014). Kapitola Gregora a Mackové má především navázat na předchozí analýzu volebních programů a seznámit čtenáře s tím, kterým tématům se v kampani strany nejvíce věnovaly a zda docházelo k vymezování se vưči konkurenčním subjektům. Ve srovnání s přechodními volbami lze tvrdit, že kampaním v roce 2013 nedominovala socioekonomická témata (přestože ekonomika a témata sociální politiky zaujímaly v programech výsostné postavenî). Konkrétního tematického vymezení se kampaně nedočkaly. Hlavní volební slogany se točily kolem „změny“ a „hledání nových alternativ“, u nových subjektů útočení proti zavedeným stranám, u neparlamentních a opozičních stran proti dosavadní politice pravicové vlády (i v posledních sněmovních volbách jsme se tedy setkávali s negativní reklamou). Jako obvykle byl kladen důraz na outdoorovou reklamu a kontaktní kampaň, a samozřejmě na internet a sociální sítě.

Vzhledem $\mathrm{k}$ tomu, že volby a předvolební kampaně jsou jednou z nejvíce mediálně atraktivních událostí ve veřejném prostoru vưbec (také díky čím dál tím silnějšímu vztahu mezi politikou a médii), není divu, že další kapitola Aleny Mackové a Lenky Hrbkové je věnována právě médiím. V předčasných volbách na podzim 2013 byl celkový význam médií do značné míry posílen viditelnou tendencí propojování mediální sféry s jedním z kandidujících subjektů (ANO), což samo o sobě přineslo poměrně významnou kontroverzi do průběhu volební kampaně a mělo za následek, že se média sama o sobě stala ostře sledovaným mediálním tématem. Obsahová analýza $\mathrm{v}$ této kapitole sleduje mediální obsahy tištěných i nových médií (ale také rádia a televize). S přibližujícím se termínem voleb prritom četnost článků věnujících se volbám rostla a vrcholila těsně před volbami. Autorky sledují nejen zmínky o jednotlivých kandidujících subjektech, 
ale také o jejich lídrech, tj. potenciálních premiérech. V žádném ze sledovaných prípadů však nedošlo $\mathrm{k}$ větší informovanosti o osobnosti než o nominujícím subjektu. Co se týče politických subjektů, nejčastěji média referovala o favorizované ČSSD na straně subjektu a o Andreji Babišovi (ANO) jako o lídrovi politické strany, obecně pak informovala především neutrálně. Negativní zabarvení článků lze sledovat především $\mathrm{v}$ př́ípadě ODS, Úsvitu a SPOZ, pozitivní konotace naopak nejčastěji u ANO a SZ. Čtvrtá kapitola mj. zachycuje také zaměření zpráv na program, aktuální dění a kampaň v jednotlivých médiích (kdy kromě Blesku převládala snaha o vyváženost informacî), stejně jako zastoupení předvolebních témat, kdy byla opět pozornost věnována převážně ekonomice.

Kapitola 5 (Roman Chytilek a Tomáš Macek) se věnuje průzkumům veřejného mínění $\mathrm{v}$ předvolebním prostředí. Periodicky o volbách prováděly výzkumy agentury CVVM a Median, mezi nejužívanější metody patřil volební model, příp. stranické preference. Většina výzkumů byla dále přebírána médii.

V kapitole 6 seznamuje Peter Spáč čtenáře s kandidátními listinami, které byly pro volby 2013 sestaveny. Jde o jeden z nejvýznamnějších procesů, které politické strany uskutečňují $\mathrm{v}$ rámci př́prav na volební soutěž. Zájem o nominační procesy $\mathrm{v}$ rámci politologie přitom stále roste, jelikož samotní kandidáti přispívají k definování strany po geografické, demografické i ideové stránce. Spáč podrobuje analýze subjekty, kterým se v daných volbách podařilo překročit 1,5\% hlasů, což zahrnuje jedenáct uskupení. $V$ drtivé většině prrípadů nominovaly strany své kandidáty ve všech volebních krajích, nicméně ne vždy byl naplněn nejvyšší možný počet nominantů (který je odvozen od počtu mandátů, které se v daném kraji rozdělujî). Analýza prokázala, že české politické strany jako primární zdroj pro nominace využívají své vlastní členské základny. Viditelnou výjimku z uvedeného trendu představovalo hnutí Tomia Okamury, které postavilo téměr plný počet kandidátů, ale pouze šest osob připadalo na členy Úsvitu a drtivou většinu tak tvořili nestraníci. Co se věku kandidátů týče, i ve volbách 2013 pokračoval trend největšího zastoupení kandidátů středního věku, hlavně v pásmu 40 až 59 let, s průměrným věkem 45,8 roku. Většina kandidátů byla mužského pohlaví, nejvíce žen nominovali Svobodní, ale také SZ a KSČM, které v nominačních procesech užívají kvóty na zastoupení žen. V celkem šesti stranách ale obsadily ženy méně než jednu pětinu nejatraktivnějších (tzn. potenciálně volitelných) míst, v dalších třech méně než jednu čtvrtinu pozic. Dalšími sledovanými skupinami byla výše dosaženého vzdělání, povolání a územní charakter listin.

V publikaci věnující se volbám jakéhokoli druhu nesmí být opomenuty výsledky, kterým se $\mathrm{v}$ tomto prípadě věnoval Vlastimil Havlík. Michal Nový posléze sledoval volební účast ve srovnání s jinými druhy voleb, její variabilitu na různých úrovních agregace a $\mathrm{v}$ různé velikosti obcí. $\mathrm{Na}$ tyto kapitoly, jimž vzhledem $\mathrm{k}$ charakteru a rozsahu této recenze a předpokládanému publiku 
nebudeme věnovat prŕlišnou pozornost, navazuje analýza Kamila Gregora týkající se přesunu hlasů, tedy kvantit voličů, kteří se ve dvojici voleb rozhodují pro různé kombinace možností. Volby 2013 znamenaly oslabení dvou dříve nejsilnějších etablovaných politických stran, ČSSD a ODS, neúspěch pro nové strany (TOP 09, VV), posílení KSČM a KDU-ČSL a vstup nových subjektů na půdu Poslanecké sněmovny (ANO a Úsvit). Gregor využívá pro analýzu bayesovský hierarchický model ekologické inference s pomocí dat agregovaných na úroveň obcí, doplněný o volební modely agentur STEM/MARK a Median ( $z$ důvodu neexistujícího exit pollu, se kterým by bylo možné porovnávat výsledky modelu). Největší část voličů, kteří se neúčastnili voleb 2010, odevzdalo svůj hlas hnutí ANO, nejčastěji doma zůstali bývalí voliči ČSSD a VV. Mezi strany s nejloajálnějším elektorátem patřila v roce 2013 ČSSD a KSČM. Zajímavý je pak případ ODS, která spadla na historické minimum voličské podpory. Zklamání voličů z vládního působení občanských demokratů a skandály uvnitř strany vedly $\mathrm{k}$ přesměrování podpory bývalých voličů $\mathrm{k} A N O$, Úsvitu a malým subjektům, které nezískaly parlamentní zastoupení. Strana nezískala prakticky žádné nové voliče. Ztráty utrpěla také TOP 09, když část jejích voličů přešla k ANO (a malým stranám). Bývalý vládní subjekt VV obdaroval ANO, Úsvit a opět malé strany. Autor se dále věnuje voličským přesunům mezi prvním a druhým kolem prezidentských voleb 2013 a danými sněmovními volbami.

Desátá kapitola Michala Pinka a Petra Vody je věnována volební geografii. Není přitom překvapující, že zhruba stejné tendence jako v předešlých volbách vykazují ČSSD a KSČM, naopak v př́padě ODS a TOP 09 došlo k prostorovým proměnám volební podpory. Zatímco KDU-ČSL obhájila svá tradiční území, hnutí ANO voliče oslovovalo napříč celou ČR. Autoři se věnují také souvislostem volební podpory mezi jednotlivými subjekty a dalšími determinanty, jako např. podíl občanů římskokatolického vyznání, podíl seniorů či podnikatelů a míra nezaměstnanosti $\mathrm{v}$ regionu.

Před volbami 2010 bylo velkým tématem preferenční hlasování, mezi jinými iniciativa Defenestrace2010.cz, která apelovala, aby voliči kroužkovali poslední čtyři kandidáty na jimi zvolené kandidátní listině, to vše s cílem personální obměny Poslanecké sněmovny. Eva Kneblová analyzuje v jedenácté kapitole využívání preferenčních hlasů ve volbách 2013. I v těchto volbách podněcovala voliče k využívání tzv. kroužků iniciativa, tentokrát Rekonstrukce státu, i přesto ale míra využívání preferenčních hlasů poklesla na 15,3 \% (oproti roku 2010, kdy činila 17,8 \%, i roku 2006 se 17,6 \%). Nejméně přitom kroužkovali voliči nových stran, ANO a Úsvitu (z parlamentních stran pak KSČM). Naopak nejvíce preferencí voliči udělili občasných demokratům, ale také KDU-ČSL. Co do využívání preferenci dle volebních krajů se nejvíce činili voliči v hlavním městě a v Jihomoravském kraji. Vůbec nejvíce pak voliči stáli o zvolení Miroslavy Němcové (ODS), která obdržela 38,2 \% preferenčních hlasů. Mezi dvacet v tomto ohledu nejúspěšnějších kandidátů nepronikl (ze subjektů, které získaly parlamentní 
zastoupenî) žádný zástupce ČSSD ani KSČM. Pouze díky preferenčnímu hlasování bylo v roce 2013 zvoleno celkem 29 poslanců a naopak každý pátý lídr krajské kandidátky se do PS nedostal. Kandidátům je v porovnání s předchozími publikacemi podobného rázu věnován větší prostor, a to v podobě kapitoly 12 , v níž se Petr Voda věnuje analýze efektu kandidáta autora. Tato kapitola plynule navazuje na předchozí pojednání o preferenčním hlasování a ptá se, jaké faktory ovlivnily výši preferenčních hlasů získaných kandidáty. Voda sleduje několik proměnných, a to pořadí na kandidátce, obhajobu mandátu, povolání, vzdělání, stranickou prŕslušnost, pohlaví, věk, bydliště a vztah k iniciativě Rekonstrukce státu. Největší efekt je na základě regresní analýzy prrisouzen faktu, zda se jedná o lídra listiny (ačkoli bylo dokázáno, že s výsledky preferenčního hlasování souvisí $v$ podstatě všechny zmíněné faktory).

Poslední kapitola diskutuje možnosti volebního inženýrství v kontextu voleb 2013. Jakub Šedo seznamuje čtenáře s úvahami o změně volebního systému pro volby do PS PČR, důraz je přitom kladen na dvě vážnější iniciativy - Prímou volbu poslancu (která usiluje o zavedení většinového volebního systému) a Demokracii 2.1 Karla Janečka (která přichází s variantou semiproporčního volebního systému s efektem více pozitivních i negativních hlasů). Již klasicky se autor věnuje také modelování výsledků voleb za užití různého způsobu přepočtu hlasů na mandáty, při úpravě počtu a velikosti volebních obvodů, či př̀i existenci a výši uzavírací klauzule.

Obecně je tak publikace Volby do Poslanecké sněmovny 2013 nadmíru užitečnou příručkou shrnující základní momenty voleb, poskytující čtenáři přehledně informace a analýzy v podobě tabulek a grafů. Na druhou stranu je nutné prriznat, že nepřináší žádné nové teorie ani hypotézy. Jedná se o přehled hlavních témat, která lze ve spojitosti s volbami sledovat, která jsou velmi přehledně zpracovaná, nicméně ve výsledku užitečná spíše jako studijní materiál (prrípadová studie) posledních proběhnuvších parlamentních voleb v Česku. Ve srovnávací perspektivě předchozích textů stejného zaměření lze za inovativní označit pouze kapitolu věnující se efektu kandidáta, kterému $\mathrm{v}$ dosavadních publikacích tohoto typu nebyl věnován takový prostor, jako právě v knize Vlastimila Havlíka a kolektivu. 